\title{
Social Media Marketing and Customer Engagement: A Review on Concepts and Empirical Contributions
}

\author{
Dissanayake D.M.R. ${ }^{1}$, Siriwardana A. ${ }^{2}$, Ismail N. ${ }^{3}$ \\ University of Kelaniya, Sri Lanka ${ }^{1,2}$, Taylor's University, Malaysia ${ }^{3}$ \\ ravi@kln.ac.lk, anushka@learning.acbt.lk, nurlida.ismail@taylors.edu.my
}

\begin{abstract}
The present context of digitalized business era reshapes marketing promotional strategies whilst social media plays a pivotal role within. Empirical investigations found clarifying how modern marketing communications connect brands into consumer life whilst claiming further investigations. Alongside, paper attempted to investigate the use of Social media in penetrating consumer engagement within the digital context. Additionally, it examines the application of web based social media marketing strategies whilst an extended focus is made on user generated contents (UGC) and social network sites (SNS) in digital business era. A deductive method was followed to execute a comprehensive literature review as the main research tool to build a constructive explanation. Accordingly, paper content empirical discussions published within the scopes of social media, consumer behavior and online businesses in overall. Paper discusses the key insights based on the literature review. Finally, it concludes the major thoughts of the paper whilst future research directions are suggested. Empirical explanations are found across the markets and product contexts unveiling how digitalized media strategies connect users to integrate with brands promoted. Such studies provide arguments and directions to overview the effectiveness of new media like social media options in business perspectives. In brief, arguments are still found claiming further studies to reveal the strategic role of social media within digitalized business era. Paper highlights the possibilities of using social media as a tool enhancing consumer engagements results brand-related behaviors. Empirical insights are discussed on how user generates contents (UGC) and social network sites (SNS) could be used in marketing applications.
\end{abstract}

Key Words: Customer Engagement, Digitalized Business Era, Social Media Marketing, Social Network Sites, User Generated Contents.

Copyright: (C) Dissanayake D.M.R., Siriwardana A, Ismail N. This is an open access article distributed under the Creative Commons Attribution License, which permits unrestricted use, distribution, and reproduction in any medium, provided the original work is properly cited.

Correspondence: ravi@kln.ac.lk

ORCID of authors: Dissanayake D.M.R - [iD IKUGVURLFIGIRUL0000-0003-3444-8439

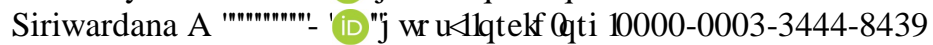

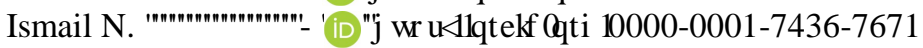

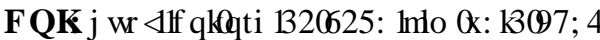




\section{Background of the Study}

Social media is a one of the widely used tools in marketing communications resulting brand- related consequences including brand awareness and customer engagements (Bento, Martinez, \& Martinez, 2018; Kim \& Yang ,2017;Larsson, 2017). The content of social media influenced promotional strategies facilitate interactive options for consumers to engage with firms, brands and even related communities with no time and place complexities (Kim \& Ko, 2012). Social media provides extended options to clients to be aware and motivated towards buying decisions on brands being influenced via posts, tweets, and pins in the platforms of Facebook, Twitter, Instagram and Pinterest (Dahlhoff, 2016). Meanwhile, in the present hyper-associated world, correspondence is quickly changing with the rise of the web and online; whereas Social Networking Sites (SNS) play a pivotal role. The biggest SNS Facebook has more than 1.96 billion dynamic clients consistently attributing the quantity of Facebook business pages have now outperformed 50 million (Statista, 2017). Those clients make 2.5 billion remarks on business pages every month, and consumers share many engaged thoughts and links providing evidence on the power of social media in businesses (Facebook, 2015; Kim \& Yang, 2017). As per the content of the SNS page of a firm (e.g. remarking on the organization and its items, communicating backing and feedback, imparting data to social associations), the online partners make coordinated duties with the firm and different customers (Dahlhoff, 2016; Moorman, 2016; Shin et al., 2015; Statista, 2017). This enables an efficient business model facilitated by digitalized value chain partners resulting competitive edge for firms. SNSs offer conceivable outcomes for this cooperation that create trust, generosity and responsibility to frame relations among people and brands paying little heed to whether those equivalent people get them (Vivek, 2009). Long term client maintenance is not just obtained and continued by direct deals, yet in addition through other coordinated correspondence channels with clients; for example, email, web-based social networking or virtual networks (Sigala, 2005). This has changed the manner in which it conveys correspondence mechanisms among brands and clients (Whiting and Deshpande, 2016). This move involves that advertising is not any more entirely one-way correspondence, where brands advise clients what and how to consider them, yet clients presently play a functioning job in making and disseminating their viewpoint on brands via internet (Whiting and Deshpande, 2016). Subsequently, brands can never again control the stream of data about them yet can just try to shape the talk (Mangold and Faulds, 2009). Thus, companies should strategically manage online channels to get the competitive edge in promoting brands whilst maintaining positive client relationships (Siriwardane \& Dissanayake, 2018). We highlight the notion of electronic word of mouth (e-WOM) as one of such powerful customer commitments to strengthening brand equity within digital business atmosphere.

Social media's role in the promotional mix of a coordinated advertising correspondence methodology is twofold; firstly, to empower organizations to converse 
with their clients; and then enabling clients to converse with each other (Faulds, 2009; Kim \& Yang, 2017; Siriwardane \& Dissanayake, 2018). The potential power and extent of chance given by Internet based life stages accompanies an entire arrangement of new purposes for promoting professional and specialist has turned into a necessary piece of advertising strategy (Larsson, 2017; Barnes, 2010). Recently found studies towards online marketing and customer brand engagements highlight how a community or individual become committed on the internet based life, effectiveness different information strategies and motivating to be alert on brand relationship behaviors. As found in the literature survey, the clients are currently controlling the substance about brands via web-based networking media (Kim \& Yang, 2017; Larsson, 2017). However, the effectiveness of social media as a tool comprised with different social networks and visual methods motivating consumer engagements; and also depicted further studies across the product categories and market contexts (Dahlhoff, 2016; Kaya \& Bicen ,2016; Moro, Cortez, \& Rita, 2018; Siriwardane \& Dissanayake, 2018). This paper discusses the purpose of the study and methodology, literature review and the discussion with conclusion and future directions.

\section{Purpose of the Study and Methodology}

Alongside the foresaid brief including the empirical highlights on knowledge requirements in the field of social media marketing, this paper attempts to review customer engagement with regards to social media whilst specific notion is made on how Customer Engagement (CE) is connected with different online brand networks (Dahlhoff, 2016; Moro et.al.2018). Supportively, contribution of Muniz and O'Guinn (2001) is regarded as the one of the pioneers presents the idea of brand networks as a promotional vehicle referring it as nongeologically bound network results social connections among admirers of a brand. A significant attention is made on practice related perspectives on the use of networks in various ways which can be communicated by remarking, sharing, enjoying, retweeting and responding to particular substance reliant on the sort SNS whilst different information sharing methods like videos are found as effective in this regard (Dahlhoff, 2016; Statista, 2017). Thus, it finds a significance to review and argue how social media as a marketing tool impacts on consumer lives and intensifies brand-related responses in the contemporary business era. A quite a lot papers direct such research needs across the boundaries of markets, generations and product scopes (Amado, Cortez, Rita, \& Moro, 2018; Dahlhoff, 2016; Kaya \& Bicen, 2016; Moro, Cortez, \& Rita, 2018; Siriwardane 2018). Accordingly, we attempt to further investigate how empirical evidences are found discussing the role the effectiveness of social media towards customer engagements in modern business context. Paper followed a deductive approach and research tool was mainly based on literature reviews (MacInnis 2004). It attempted to review empirical thoughts as an organized content on how social media connects to consumer engagement process in different faces and how Customer Engagement (CE) is connected with different online brand networks finally concluded the main remarks whilst proposing key insights for the future research directions. 


\section{Literature Review}

This paper presents the literature review by mainly focusing on empirical overview on social media and consumer engagement whilst specific attention is made towards the convergence on social media and its impact on consumer engagement. Additionally, content explains how social media emerged as denoted in empirical studies.

\section{Influence of Social Media Marketing}

Over the previous decades, associations have been perceiving the potential effect of social media on corporate world reputation and associations with partners by bringing web based life into their advertising systems to draw in with clients (Amado et.al.2018; Moro et.al.2018). Social media is changing the patterns of hierarchical correspondence and advertising. As per Parveen, Jaafar and Ainin (2016) online life opens two-way correspondence empowering associations to all the more likely comprehend their clients wanted needs and needs and how to adequately react to those needs. However, if associations are to utilize new advances and techniques to additionally increment authoritative execution, these strategies must be embraced legitimately (Parveen, et.al.2016). The quickly developing computerized condition and the high impact of social media have monumentally affected showcasing, client conduct and eorganizations rehearses (Shin \& Kim, 2015). Shin and Kim (2015) contended that each feature of corporate correspondence is modifying as an outcome of online networking. Organizations have less power over interchanges while contenders and shoppers have more noteworthy access to data than at any other time. Thus, correspondences have turned out to be more powerful and less static (Argenti, 2006). The corporate messages were communicated to people with the target to educate or influence them to follow up on a specific practice to acknowledge corporate objectives (Schultz \& Kitchen, 2004). Today, innovation obliges ongoing exchange among organizations and stakeholders blessed by digitalized communication options including social media.

Meanwhile, Herold (2017) directed an investigation reporting $52 \%$ of online life advertisers web-based social networking has affected their organizations to expand deals and income. Besides, it discovered that the most significant web based life stages utilized by organizations were Facebook (89\%), LinkedIn (83\%), YouTube $(81 \%)$ and Twitter $(80 \%)$ respectively. In addition, Instagram placed as the fifth option reporting 56\% of references. However, Instagram is anticipated to increment significantly in the coming years. At present social media provides an extended option for marketers to trace consumer attention to build brand awareness and engagements (Dahlhoff, 2016; Statista, 2017). As indicated by Toder (2016), internet-based life is imperative and considerably $90 \%$ of youthful will utilize web-based life. Interestingly, Grillo (2017) contends that web based life channels proceed to develop more than $33 \%$ or 2.62 billion individuals as dynamic online life clients. Worldwide associations utilize distinctive internet based life stages i.e. Brand site, Facebook and Twitter to create associations with their partners (Dahlhoff, 2016; Shin et al., 2015). Moreover, it uncovered that $44.1 \%$ of associations say they haven't possessed the capacity to distinguish the effect of 
their internet based life spending (Moorman, 2016). Thus, comprehensive methods and empirical works should be there to revisit how internet based life is productive to commercial firms.

\section{Review on Consumer Engagement}

Firms are perceiving the squeezing need of building individual two-route associations with clients who cultivate collaborations (Kumar, 2010). Customer Engagement (CE) has been perceived as an enthusiastic association between an organization and its customer concentrated on collaboration with clients and their support. Some studies highlight how e-commerce which is known to be a strategy implemented in online context, creates e-loyalty via promotional activities (López-Miguens \& González-Vázquez 2017). Usually, consumer engagement and brand evaluations could result loyalty behavior committing long term benefits for a brand (Dissanayake \& Ismail, 2015; Keller, 2012). Social media is one of the facets which enables such extended customer relationships resulting strategic advantages for a brand and corporate (Siriwardane \& Dissanayake, 2018).

The key component to customer engagement is learning trade, so data and correspondence innovations give tremendous chances to associations to trade information and draw in with clients (Vivek, 2009). Bowden (2009) comprehended customer engagement as a mental procedure that models the hidden instruments by which client devotion is attributed to obtain new clients. Supportively, Vivek, (2009) characterized client commitment as the power of individual interest and association with the offers and exercises of the association started either by the client or by the association. The specific instance of online client commitment was characterized by Mollen and Wilson (2010) as the psychological and full of feeling duty of the customer to a functioning association with the brand as exemplified by the site. Every one of these ideas speaks to a solitary hypothetical degree, which has muddled the accomplishment of more prominent applied advances, mirroring the absence of supreme accord (Hollebeek, 2013). In any case, it might in reality be reasoned that the lion's share utilizes a multidimensional point of view on commitment with three measurements: intellectual, passionate and conation (Vivek, 2009). Despite the fact that self-articulation of these nonexclusive measurements can change particular idea of commitment that is utilized with unique circumstances (Brodie, 2013).

For the most part, customer engagement is seen as esteem expansion from a customer to a business (Pansari \& Kumar, 2017). Today, the estimation of customer engagement goes past moneyrelated prospect and it is fairly a street to imperative business goals (Solomon, 2015). It offers ascend to mark mindfulness, reinforces client loyalty, enhances mark esteem and consumer satisfaction (Pansari \& Kumar, 2017). Despite the fact that accomplishment of objectives is a vital inspiration for organizations to cultivate client commitment, the real receptive or proactive reactions are in actuality in the hands of buyers rather with organizations as how it was (Larsson, 2017). With the presentation of the web, the present clients have more power. Internet based life enables not just firms to impart data to their clients, yet additionally clients to impart data to one another (Sashi, 2012). They can impart 
their insights with the world in merely seconds, conceivably annihilating a business or making it a win (Kumar, 2010). On that account, organizations must be exceptionally watchful with regards to building their association with clients. Web based life upsets client commitment resulting more engagements (Bento, et.al. 2018; Kim \& Yang, 2017)

Thus, it could argue social media provides an extended option to business firms over the tradition media to make aware, motivate to buy and even to establish continuous relationship with the brands and respective corporates. It could result a well-connected brand community via such extended application of social media strategies which is another interesting research direction (Dissanayake, 2018). Derived from looks into done beforehand, associations progressively look for duty and support through their brands (Prahalad \& Ramaswamy, 2004). People are never again observed as negligible aloof beneficiaries of advertising activities from the point of view of client commitment, however, progressively as proactive members in intelligent procedures of co-creations (Shawhney, 2005). It has been recommended that customer duty produces upgraded hierarchical execution, including expanded deals, unrivaled upper hand and benefit ( Hollebeek, 2011), enthusiastic associations/connection (Chan and $\mathrm{Li}$, 2010) and strengthening and purchaser esteem (Schau, 2009). Online networking advertising not just escalating the current firm to client and client to firm connections, yet additionally make new minor departure from regular choices expanding the capacity of firms to associate in firmclient exchange whilst reinforcing their correspondences. There are basic changes in the simplicity of contact, volume, speed, and nature of cooperation (Gallaugher \& Ransbotham, 2010). Firms can connect with individuals that generally could not be achieved (Newman, 2003). Webbased social networking exchanges substance to a more different scope of individuals contrasted with broad communications. They make a small world arranged and system is shaped through willful association ensuring less strides for sharing data (Newman, 2003). Customer conduct has regularly impacted suggestions and referral on items and administrations. The drivers of new item proposals and referral conduct on informal community are basic to buying behavior. In general, web-based publications designed with positive properties are invited by clients; nonetheless, advertisements that are meddle with online long-ranged interpersonal communication exercises are disdained by system clients (Whiting \& Deshpande, 2016). For instance, system clients tend to disdain fly up, expandable, or drifting arranged promotions (Kim \& Yang, 2017). Those are the new challenges found in contemporary business era to maximize the outcomes of marketing promotional strategies. A cluttered online media may have complexity loading effect on users that drains the effectiveness of social media marketing campaigns. The utilization of online networking by advertisers has been consistently expanding, but generally few organizations have encountered an expansion in customer engagement (Barger, Peltier, Schultz, 2016). This may be reason on less strategic focus held on web-based networking media (e.g. offering items). The initiations on building relations through customer engagement (CE) has not been a need in 
a web-based life that results coinnovative and intelligent practices (Barger \& Labreque., 2013; Bento, et.al.2018).

\section{Social Media Marketing and its Impacts on Consumer Engagement}

Meanwhile, Barger et. al. (2016) justified arrangements of five predecessors to generate $\mathrm{CE}$ on social media. First of all, the level of CE is impacted by clients' disposition towards a specific brand. Sharing of substance has been found not exclusively be affected by the substance as such yet in addition to the client's disposition toward the brand conveying the substance. Secondly an arrangement of item related components can influence CE via web-based networking media, which includes client's involvement with an item or administration. Thirdly, client based variables can likewise impact the dimension of client commitment via web-based networking media. Clients have been found to draw in with internet-based life for various reasons including amusement, the requirement for data, social relations and impression administration (Barger et. al. 2016; Kim \& Yang, 2017). The fourth of CE is content elements, which incorporate the message offered and passionate conclusion. Clients will probably connect with posts that convey an enthusiastic assumption and more averse to draw in with presents attempting on offer an item (Swani 2013). Furthermore, the striking quality of substance has additionally been connected to post commitment via webbased networking media. Lastly Barger et al. (2016) recommend that the social medium itself can affect the sort and level of CE yet just a rare measure of research has investigated the contrasts between the present a wide range of online networking from a client commitment point of view. Supportively, these five components influence how clients associate with brands via web-based networking media, which will impact the effect of the commitment on the firm. Doorn (2011) referred CE established via webbased networking media can have ramifications for how clients see a brand and its items (Barger et al., 2016). Those outcomes can be fortified by the intrinsic sharing outcomes of webbased life, where data is disseminated in the client's very own social arrange. This is particularly fascinating thinking about that clients have the best state of mind towards information proposed by merchants (Kim \& Yang, 2017).

\section{Discussion}

Paper reveals an extended explanation on how social media acts in relation to creating customer engagement whilst supportive contents are also presented as clarifications. Accordingly, undermentioned explanations are presented with empirical clarifications.

\section{The Influence of Social Media Marketing on Consumer Engagement}

Client commitment is considered as a conduct towards the brand or firm that goes past exchanges (Verhoef, 2010). Models of client commitment practices include; discussing the brand to loved ones, verbal movement, suggestions, helping different clients, blogging furthermore and composing surveys. Inside late years, the idea of customer engagement has developed in the advertising writing aiming clarifying the communications between customer and brands (Mollen \& Wilson, 2010). It characterizes customer engagement as a customer's conduct towards a brand. Customer engagement includes 
encounters or collaborations between a subject (a client) and a question relates to brands, sites and different clients (Mollen \& Wilson, 2010). Client commitment has been denoted as a strategic influence for future business executions (Sedley, 2008), deals development (Neff, 2007), improved benefit (Voyles 2007) and also an apparatus for picking up an upper hand (Brodie, Juric \& Hollenbeek, 2011). It is evident empirical justifications denote social media or and online communication tools need result customer commitment rather limiting their role as informational source. This enables brands or firms to assure strategic gain out the investment it incurs (Grillo, 2017).

\section{Application of User Generated Contents (UGC)}

In the web 2.0 setting, shopper commitment is obvious through the methods for distributing, posting remarks, buying, bookmarking, and messaging and systems (Kim \& Yang, 2017). When estimating commitment, the dimension of client cooperation is an undeniable and imperative segment, and its activity demonstrates an alternate dimension of engagement. The consumer online brand-related exercises can be arranged into three measurements within web-based social networking namely expending, contributing and making (Verhoef, 2010). A client who remarks on an authoritative post on a corporate blog is at a more elevated amount of commitment than one who essentially peruses the post. Shoppers, particularly the individuals who are individuals from dynamic networks could create content that leads a higher reverberation among other Web clients (Verhoef, 2010). Supportively, development of User Generated Content (UGC) has been amazing and business firms have rushed to seize upon UGC as another approach to make commitment with their brands. (Mollen \& Wilson, 2010) Clients can create an incentive to the firm through more routes than just their buy products. (Brodie, Juric \& Hollenbeek, 2011). Consequently, firms should center on client commitment esteem (CEV), which offers a more entire assessment of how much an individual client is adding to the firm in various ways. As per Kumar (2010), the estimation of client commitment is included four center measurements: client obtaining conduct, client referral conduct, client influencer conduct and client learning conduct. The online social networks also make extended impact on consumers and brands. It proves passionate interests in brand-related posts on Facebook and Twitter influence Consumer Engagement Behavior CEB (Todor, 2016). Thus, we also confirm UGC and the related communication contents including electronic word-of-mouth (e-WOM) act as an effective content source that influences favorable consumer engagement impacts.

\section{The Role of SNS and Different Marketing Applications}

Long ranged SNS could structure in which clients are presented to messages that are being locked by their systems (Swani, Milne \& Darker, 2013). This can both be an intentional activity, where a client imparts substance to their system (e.g. through a share or retweet work), and less intentional, when a client remarks or responds to a message. As indicated by Ross (2014), a correlation between post commitment and achieve (a measure for what number of clients that are exposed to the post) can be set up within SNS 
atmosphere. The reason for brands to be available on SNS can subsequently be viewed as twofold; firstly, they can strengthen relations with clients through customer engagement (Barger, Peltier and Schultz, 2016), and then expanding brand exposure to more clients through the intrinsic system structure of a SNS (Ross, 2014). Implementing the elements of customer engagement via web-based networking media is a zone that is amazingly profitable to advertisers whereas it was predicted substantial amount of advanced promotional plans would be available on social media networking in the US (eMarketer, 2015). Currently, this has been a proven reality even within emerging economies.

Researches in the field has tried to uncover a portion of these elements by examining how enthusiastic correspondence and distinctive post qualities influence customer engagement. De Vries (2012) discovered that the distinctiveness of posts (the degree to which a post invigorates diverse faculties) is connected to the quantity of preferences a post gets. In their correlation of B2B and B2C post popularity on Facebook, Swani (2013) explored the effect of various message techniques, and discovered that a "call to buy methodology" produces generally more likes in a B2C setting contrasted with a $\mathrm{B} 2 \mathrm{~B}$. Then again, past investigations in different territories of researches discovered contrasts between the impact of enthusiastic interests in B2B and B2C setting. Meanwhile, Lothia, Donthu and Herschberger (2003) discovered that a passionate intrigue emphatically influences the viability of online pennant promotions in a $\mathrm{B} 2 \mathrm{C}$ setting, while at the same time doing the inverse in a B2B setting. In the field of relational correspondence, the impression of enthusiastic substance in messages has been found contrast from how the sender's aim of the email (Byron, 2008). Accordingly, collectors will be in general see feelings more contrarily or impartial than indented by the sender (On the same page). Byron (2008) clarifies this matter by suggesting that the data wealth of message influences how feelings are seen. Thus, eye to eye correspondence has the most elevated level of data extravagance, while email correspondence is less fatty. Thus, it denotes interactivity could find more engaged results for a brand being promoted in social media networks.

Derived from investigations done beforehand, associations progressively look for duty and support through their brands (Prahalad \& Ramaswamy, 2004). As per said, people are never again observed as negligible passive collectors of promoting activities from the viewpoint of client commitment, however, progressively as proactive members in intuitive procedures of cocreation that produce esteem. It has been recommended that customer duty creates upgraded authoritative execution; including expanded deals, unrivaled upper hand and profitability passionate associations/connection eventually strengthening and buyer esteem (Chan \& Li, 2010). Web-based life showcases not just heighten the current firm to client and client to firm connections; yet in addition make new minor departure from customary choices expanding the capacity of firms to interface in firm-client exchange. There are major changes in the simplicity of contact, volume, speed, and nature of these collaborations (Gallaugher \& Ransbotham, 2010). Firms can connect with individuals that 
generally couldn't be achieved (DongHun, 2010; Newman, 2003). Online networking exchange substances to a more differing scope of individuals contrasted with broad communications. They make an organized small world within social networks (Newman, 2003). Such options could create contents effectively to motivate willful association demanding less strides for sharing data. Thus, modern web-based life is to be attributed by innovative methods to craft the information contents with creative insights and simplicity to motivate much penetrated dissemination.

\section{Conclusion and Future Research Directions}

In general, brands create brand relationship behaviors provided it finds enough consumer-brand bond which has also been mentioned as agency between consumer and the said brand (Kahadawarachchi, Dissanayake \& Maitra, 2016: Keller, 2012). Consumers or users engage with brands via information and experience related matters in new media (Larsson, 2017). Referring to online context, clients take a functioning part in shaping the talks encompassing brands and items in the online network (Kim \& Yang, 2017; Siriwardane, 2018; Whiting and Deshpande, 2016). Additionally, Parveen, Jaafar \& Ainin (2016) confirm social media as an effective content option to support organizational performances.

The digitalized economy results online life changes the manner in which brands and clients collaborate (Todor, 2016). In brief, information communication technology (ICT) influences communities to connect with different economic contexts (Dissanayake,
2011). We highlight that ICT enabled communities could connect and expose intensively towards digitalized marketing campaigns. However, advertisers find it difficult to control the online dialog, but can just look to shape it (Mangold and Faulds, 2009). According to Todor (2016), unique passionate interests in brand posts on Facebook and Twitter significantly influence Consumer Engagement Behavior (CEB). This alarms the validity of social media to create effective commercial outcome rather limiting to social interactions. Meanwhile-commerce has been noted as a rapidly growing marketing tool in emerging economies (Elbeltagi \& Agag, 2016). However, extended investigations are needed to search how those countries strategically use social media to support commercial relationships leading competitiveness. We also highlight innovative business models supported by social media strategies as a timely important need for emerging economies to expand market potentials.

Ongoing advances on the web and the improvement of online networking have encouraged to penetrate widely available shoppers. Shoppers have social cooperation through web-based life; for example, online discussions, communities, ratings, surveys and suggestions make it more engaged with brands. These improvements have presented another stream in online business called social trade; which enables shoppers to create substance and impact others. These collaborations give diverse qualities to both business and shoppers. Taking everything into account, it has discovered that retailers can expand consciousness of their image by being imaginative via webbased networking media (Parveen, 
et.al.2016; Siriwardana, 2018).Today, associations are challenged by the quickly changing advertising condition commanded by developing internetbased life utilize. Conventional television is being supplanted with services, for instance; Netflix and Apple television are supplanting radio in spite of the fact that achieving clients is not an issue. We emphasize that customary media still has a functioning job in the promotion mix, but requires integrated marketing communication with an extended media mix (Shimp, 2010). At its center, conventional advertising conveys to shoppers through a restricted correspondence (Todor, 2016). Interestingly, web-based life could be utilized by organizations to effectively draw in with their intended interest group through two-way correspondence. Online networking empowers organizations to focus on their clients with the attention on building brand associations (Parveen, 2016). Additional examination is defended concerning which web-based life exhibiting techniques are convincing for little retailers. In brief, firms should focus to penetrate online communication strategies to upgrade

\section{References}

Amado, A., Cortez, P., Rita, P., \& Moro, S. (2018). Research trends on Big Data in Marketing: A text mining and topic modeling based literature analysis, European Research on Management and Business Economics, 24(1), 1-7.

Argenti, P.A. (2006). How Technology Has Influenced the Field of Corporate Communication, Journal of Business and Technical Communication, 20(3), 357-370. relationship with their customer base (Siriwardana \& Dissanayake, 2018). There is a clear knowledge gap and practice-related necessity to further examine how social media results brand impacts and client commitment. A portion of these territories of research is obviously immature and requires comprehensive investigations within emerging economies (Elbeltagi \& Agag 2016; Swani,et.al. 2013). As it empirically supported, social medial marketing practices are found examined with different products,cultures,brand equity models and comparative market scopes highlighting cost and return benefits within ((Barger et al. 2016; Kim \& Yang, 2017; López-Miguens \& González-Vázquez 2017; Riquelme, Román, \& Iacobucci,2016). Alongside, we also denote future research directions to extendedly investigate how social media influences consumer engagement towards different long term brand relationship behaviors. We encourage such studies to focus on different interim mechanisms related to demographic and customer cognitive factors when researching brand relationship behaviors within the digital marketing context.

Barger, V, Peltier, J.W \& Schultz, D.E. (2016). Social media and consumer engagement: A review and research agenda. Journal of Research in Interactive Marketing, 10(4), 268-287.

Barger, V.A \& Labrecque, L. (2013). An integrated marketing communications perspective on social media metrics. International Journal of Integrated Marketing Communications, 15(4), 65-76. 
Barnes, N. (2010). Tweeting and blogging to the top. Marketing Research, 34(6), 8-13.

Bento, M., Martinez, L. M., \& Martinez, L. F. (2018). Brand engagement and search for brands on social media: Comparing Generations $\mathrm{X}$ and $\mathrm{Y}$ in Portugal, Journal of Retailing and Consumer Services, 43, 234-241.

Brodie, R.J. (2013). Consumer engagement in a virtual brand community: an exploratory analysis. Journal of Business Research, 66(1), 105-114.

Brodie, R.J, \& Juric, B. (2013). Consumer engagement in a virtual brand community: An exploratory analysis. Journal of Business Research, 66(1), 65-72.

Bowden, J.L.H. (2009). The process of customer engagement: a conceptual framework. Journal of marketing theory and practice, 17(1), 63-74.

Dahlhoff, D. (2016). The Challenge for Luxury Retailers: Figuring Out Digital Opportunities. In Online Luxury Retailing: Leveraging Digital Opportunities: Research, Industry Practice, and Open Questions. Philadelphia: Wharton School, Baker Retailing Center.

Dissanayake, D.M.R. Information Communication Technology (ICT) Policy of Sri Lanka and its Impacts to Socioeconomic Development: A Review of Sri Lankan Experience, Journal of Education and Vocational Research, Vol. 1, No. 2, pp. 53-59.

Dissanayake, D.M.R. \& Ismail,N. (2015). Relationship between Celebrity
Endorsement and Brand Attitude: With Reference to Financial Services Sector Brands in Sri Lanka, Conference proceedings, International Conference on Business \& Information (ICBI), 122.

Elbeltagi, I. and G. Agag,(2016). "Eretailing ethics and its impact on customer satisfaction and repurchase intention", Internet Research, Vol. 26 No. 1:288-310.

Facebookcom. (2015). Retrieved 20 November, 2018, from https://www.facebook.com/business/ne ws/new-tools-for-managingcommunication-on-yourpage?

Faulds, W.M. (2009). Social Media: The new hybrid element of the promotion mix. Business Horizons, 20(3), 357-365.

Gallaugher, J \& Ransbotham, S. (2010). Social media and customer dialog management at starbucks. MIS Quarterly Executive, 9(4), 197-212.

Grillo, F. (2017). Social Media: Considerations for B2C vs B2B. Retrieved 15 November, 2018, from http://www.marketingjournal.org/socia l-mediaconsiderations- for-b2c-vs-b2bfrank-grillo/

Herold, K. (2017). How Businesses Use Social Media: 2017 Survey . Retrieved 19 November, 2018, from https://clutch.co/agencies/socialmediamarketing/resources/socialmedia-survey-2017

Hollebeek, L.D. (2011). Demystifying customer brand engagement: exploring the loyalty nexus. Journal of marketing management, 27(8), 785-807. 
Hollebeek, L.D. (2013). The customer engagement/value interface: an exploratory investigation. Australasian Marketing Journal, 21(1), 17-24.

Kahadawarachchi,

L.K.K., Dissanayake, D.M.R. \& Maitra,R. (2016). Role of Relative-Agency of Consumers in Brand Building: Conceptual Review for Marketing Implications and Future Studies, Sri Lanka Journal of Marketing (SLJM), Vol 2, Isue 3, 35-58.

Kaya, T., \& Bicen, H. (2016). The effects of social media on students' behaviors; Facebook as a case study, Computers in Human Behavior, 59, 374-379.

Kim, C., \& Yang, S. U. (2017). Like, comment, and share on Facebook: How each behavior differs from the other, Public Relations Review, 43(2), 441449.

Kim, A. J., \& Ko, E. (2012). Do social media marketing activities enhance customer equity? An empirical study of luxury fashion brand, Journal of Business Research,65(10), 1480-1486.

Kumar, V. (2010). Undervalued or overvalued customers: capturing total customer engagement value. Journal of service research, 13(3), 297-310.

Larsson, A. O. (2017). Diversifying Likes: Relating reactions to commenting and sharing on newspaper Facebook pages, Journalism Practice, $1-18$.

López-Miguens, M. J. and G. V. Encarnación. (2017). “An integral model of e-loyalty from the consumer's perspective". Computers in Human Behavior, Vol. 72:397-411.
Macinnis, D. (2004). Where Have All the Papers Gone. Association for Consumer Research Newsletter, 21(2), 1-3.

Mangold, W.G \& Faulds, D.J. (2009). Social media: The new hybrid element of the promotion mix. USA: Elsevier Advanced Technology Publications Elsevier Science Ltd.

Mollen, A \& Wilson, H. (2010). Engagement, telepresence and interactivity in online consumer experience: Reconciling scholastic and managerial perspectives. Journal of Business Research, 63(9), 919-925.

Moorman, C. (2016). The CMO Survey update: Social Media Falls Short of Expectations. Retrieved 23 November, 2018, from http://www.marketingjournal.org/thecmo-survey-update-social-media-fallsshort-ofexpectations- christinemoorman/.

Moro, S., Cortez, P., \& Rita, P. (2018). A divide and conquer strategy using feature relevance and expert knowledge for enhancing a data mining approach to bank telemarketing, Expert Systems, 35(3), e12253.

Nair, M. (2011). Understanding and measuring the value of social media. Journal of Corporate Accounting \& Finance, 22(3), 45-51.

Neff, J. (2007). What's the value of an engaged viewer? Advertising Age. Retrieved 18 November, 2018, from http://adage.com/article/119064/

Newman, M. (2003). The structure and function of complex networks. SIAM Review, 45(2), 167-256. 
Pansari, A \& Kumar, V. (2017). Customer engagement: the construct, antecedents, and consequences. Journal of the Academy of Marketing Science, 45(3), 294-311.

Parveen, F. (2016). Social media's impact on organizational performance and entrepreneurial orientation in organizations. Management Decision, 54(9), 2208-2234.

Parveen, F, Jaafar, N.I \& Ainin, S. (2016). Social media's impact on organizational performance and entrepreneurial orientation in organizations. Management Decision, 56(4), 2208-2234.

Prahalad, C.K \& Ramaswamy, V. (2004). Co-creation experiences: the new practice in value creation. Journal of interactive marketing, 18(3), 5-14.

Riquelme, I. P., Román, S. and D. Iacobucci.(2016). "Consumers' Perceptions of online and offline retailer deception: A moderated mediation analysis". Journal of Interactive Marketing, Vol. 35:16-26.

Sashi, C.M. (2012). Customer engagement, buyer-seller relationships, and social media. Management Decision, 50(2), 253-272.

Schau, H.J, Muniz, A.M \& Arnould, E.J. (2009). How brand community practices create value. Journal of marketing, 73(5), 30-51.

Schultz, D.E \& Kitchen, P.J. (2004). Managing the Changes in Corporate Branding and Communication: Closing and Re-opening the Corporate Umbrella. Corporate Reputation Review, 6(4), 347-366.
Sedley, R. (2008). Six theses on digital customer engagement in a troubled economy. Retrieved 21 November, 2018, from http://richardsedley.iuplog.com/default.asp?item $=29$ $\underline{8747}$

Shawhney, M, Verona, G \& Prandelli, E. (2005). Collaborating to create: the internet as a platform for customer engagement in product innovation. Journal of interactive marketing, 19(4), 4-17.

Shin, W. (2015). Building Relationships through Integrated Online Media: Global Organizations' Use of Brand Web Sites, Facebook, and Twitter Journal of Business and Technical Communication. Journal of Business and Technical Communication, 29(4), 184-220.

Shimp, T.A. (2010). Advertising Promotion and other Aspects of Integrated Marketing Communications, $8^{\text {th }}$ Edition, Mason, OH: South Western Cengage Learning.

Sigala, M. (2005). Exploring the transformation of tourism firms 'operations and business models through the use of web map services. Retrieved 24 November, 2018, from Izmir,

availablewww.iseing.org?emcis/cdrom $\% 20$ proceedings $\% 20$ referred $\% 20$ paper s/proceedings/presenting\%20papers/c 7 2/c72.pdf?

Siriwardana, A. (2018). Role of Social Media towards Consumer Behavioral Perspective, International Journal of Social Sciences and Management Review, 1(1), 30 - 40.

Siriwardana \& Dissanayake, D.M.R. (2018). Social Customer Relationship Management (SCRM) in Contemporary 
Dissanayake D.M.R., Siriwardana A, Ismail N, KJM, 2019, 08 (01)

Business Era, International Journal Business and Management Invention (IJBMI), 7(9), 59-64

Solomon, M. (2015). Customer engagement is everything In business. Retrieved 22 November, 2018, from https://www.forbes.com/sites/micahsol omon/2015/12/24/customerengagement-iseverything/\# 386a05b9466b

Statistacom. (2017). Statista. Retrieved 17 November, 2018, from https://www.statista.com/statistics/272 014/global-socialnetworks

Economic Sciences Series V; Brasov, 9(1), 51-56.

Van doorn, J. (2010). Theoretical foundations and research directions. Journal of Service Research, 13(3), 253-266.

Verhoef, P. (2010). Customer Engagement as a New Perspective in Customer Management. Journal of Service Research, 13(3), 456-465.

Vivek, S. (2009). A scale of consumer engagement. Retrieved 12 November, 2018, from http://acumen.lib.ua.edu/content/u0015 /0000001/0000096/ u0015_0000001_0000096.pdf

Voyles, B. (2007). Beyond loyalty meeting the challenge of customer engagement. The Economis Intelligence unit, 54(11), 1-14.

Whiting, A \& Deshpande, A. (2016). Towards greater understanding of social media marketing: A review. The Journal of Applied Business and Economics, 18(4), 82.
Statistacom. (2018). Statista. Retrieved 28 November, 2018, from https://www.statista.com/statistics/278 414/number-of-worldwide-socialnetworkusers/

Swani, K. (2013). Spreading the word through likes on Facebook. Journal of Research in Interactive Marketing, 7(4), 269-294.

Todor, R.D. (2016). Blending traditional and digital marketing. Bulletin of the Transilvania University of Brasov 